\title{
Transdisciplinary, Community-Engaged Pedagogy for Undergraduate and Graduate Student Engagement in Challenging Times
}

\author{
Shoshanah Jacobs ${ }^{1,2}$, Christine E. B. Mishra ${ }^{1}$, Erin Doherty ${ }^{3}$, Jessica Nelson ${ }^{1}$, Emily Duncan ${ }^{4}$, Evan D. G. Fraser ${ }^{5}$, \\ Kelly Hodgins ${ }^{6}$, William Mactaggart ${ }^{7} \&$ Daniel Gillis $^{8}$ \\ ${ }^{1}$ Department of Integrative Biology, University of Guelph, Canada \\ ${ }^{2}$ Office of Educational Scholarship and Practice, University of Guelph, Canada \\ ${ }^{3}$ J. F. Woods Centre for Business and Student Enterprise, University of Guelph, Canada \\ ${ }^{4}$ Department of Geography, Environment and Geomatics, University of Guelph, Canada \\ ${ }^{5}$ Arrell Food Institute, University of Guelph, Canada \\ ${ }^{6}$ McConnell Foundation, Montreal, Quebec, Canada \\ ${ }^{7}$ The Oak Tree Project, Guelph, Ontario, Canada \\ ${ }^{8}$ School of Computer Science, University of Guelph, Canada \\ Correspondence: Shoshanah Jacobs, Department of Integrative Biology, University of Guelph, Guelph, ON., N1G \\ 2W1, Canada.
}

Received: July 23, 2021

doi:10.5430/ijhe.v10n7p84
Accepted: September 7, 2021

Online Published: September 15, 2021

URL: https://doi.org/10.5430/ijhe.v10n7p84

\begin{abstract}
When the COVID-19 pandemic required all higher education learning to move to remote or online formats, students were challenged to maintain a sense of community and to advance in their education. By focusing on the immediate, human needs of students, IdeasCongress - a community-engaged experiential learning course with a curricular emphasis on transferable skills - flourished in the remote synchronous format. The only significant change was to shift the topic of the course to \#RecoverTogether to guide our students in imagining a path through the pandemic while supporting local charities by developing plans for mitigating the impact that the pandemic was having on their service model. This paper outlines a case study of the course and reflections upon the experience of teaching during the pandemic restrictions, supported by student feedback from the September-December (Fall) 2020 semester. Based on this evidence, the approach appeared to be effective for student retention and engagement, and increased student feelings of connectedness to both the campus and the local community. The paper highlights key lessons learned while teaching and learning during challenging times and describes the teaching approaches used to support students.
\end{abstract}

Keywords: remote learning, community-engaged learning, experiential learning, first year students, mentorship, COVID-19

\section{Introduction}

\subsection{Impact of COVID-19 on Higher Education}

The global shift of higher education classes from in-person to online in response to the COVID-19 pandemic has led to the widespread search for effective teaching and learning approaches in this remote format (Christian, McCarty, \& Brown, 2020; Hodges, Moore, Lockee, Trust, \& Bond, 2020; Mishra, Gupta, \& Shree, 2020; Schwartzman, 2020). Once classes were shifted online on an emergency basis in March 2020, university adminstrators turned their attention to the next academic year with plans for a primarily remote format using a combination of synchronous and asynchronous deliveries (Johnson, Veletsianos, \& Seaman, 2020; MarketScale, 2020; UNESCO Education Sector, 2020d). Due to varying levels of access to digital remote tools, and the rushed implementation of emergency remote instruction, the learning experience became much more challenging for many students. At the same time, students are increasingly isolated and have reduced access to most aspects of campus life and services which would normally foster connection and community outside of the curriculum (Christian et al., 2020; Mishra et al., 2020; Schwartzman, 2020).

Many approaches to emergency remote instruction (e.g. synchronous lectures using video conferencing software, asynchronous pre-recorded lectures paired with discussion boards, or with synchronous breakout room discussions), 
have simply maintained the traditional instructor-centered pedagogy while using digital tools. Christian et al. (2020, p. 2) argue that "translating an exact replica of an in-person course to online format during COVID-19 is ... misguided as it neglects to consider the ... personal, psychological, and logistical concerns of students and professors". Several reports on Tertiary Education during the COVID-19 pandemic called for a paradigm shift from this traditional model to approaches that are more innovative, interactive, and student-centred, where the instructor takes more of a facilitator role (Gallagher \& Palmer, 2020; UNESCO Education Sector, 2020c, 2020d). In addition, the combined health and economic crises caused by the pandemic also accelerated many existing trends in the labour market, including the need for students to gain a strong set of transferable skills, (also called generic, key, soft, foundational, or cross-functional skills) that will allow them to be more effective in the workplace and to shift careers, fields, and types of work more easily (Royal Bank of Canada [RBC], 2018; UNESCO Education Sector, 2020a, 2020b).

Courses that already centered students through experiential learning, including courses that used community engagement components and those with an applied or skill-building focus, have had to be more deliberate and creative in their approaches to keep meeting these goals in the remote setting. They found ways to continue their interactive and engaging teaching and learning strategies even in these challenging times (Christian et al., 2020; UNESCO Education Sector, 2020d), to offer quality teaching and learning and to build a sense of community for students. It has also become clear that students increasingly want to gain the skills and experience necessary to make an impact in the world and to be change-agents, as seen by the recent increase in large youth-led movements such as the Youth Climate Strikes and the Black Lives Matter protests (Huish, 2021). To do this meaningfully, institutions of higher education must intentionally increase community engagement during and after this crisis (UNESCO Education Sector, 2020c).

In the absence of a revolution in education, instructors are charged with designing and delivering the best courses possible with the available resources. To engage students in the remote setting due to the worldwide pandemic, instructors needed to design learning experiences that were 1) accessible for all their students, 2) able to facilitate meaningful social connections, and 3) relevant to ongoing, large-scale social change without invoking further trauma.

The purpose of this paper is to describe the modifications necessary to support undergraduate and graduate students in a community-engaged collaborative experience during the COVID-19 pandemic when the usual modes of teaching and learning have been challenged. The paper explores a narrative case study of the IdeasCongress course experience, with reflections of the instructors and a community partner, and data from a student feedback survey.

\subsection{What is the IdeasCongress (ICON) Course?}

The IdeasCongress (ICON) course was designed to be an experiential learning opportunity with reduced barriers to entry - since it is offered for credit and within the regular academic schedule - for students to focus their attention on developing transferable skills and to put those skills into action while working on a community-based challenge. Students from any year level and any discipline can enroll from a variety of course codes that best serve their academic degree requirements (Gillis et al., 2017; Jacobs, Nelson, Driscoll, \& Gillis, 2017; Jacobs \& Gillis, 2016). The instructors practice a pedagogy that centers and humanizes student learning, modelling the transferable skills that they teach within a course built upon the principles of Universal Design for Learning (Burgstahler \& Cory, 2008).

The ICON course is offered at the University of Guelph, a midsize comprehensive university which confers undergraduate to doctoral degrees in Ontario, Canada with approximately 27,000 undergraduate and 3,000 graduate students (Office of Institutional Research and Planning, 2020). ICON was first offered in January-April (Winter) 2015, and it has now run a total of 11 times, with almost 400 students participating, from first year to upper year undergraduate students.

Each class typically includes a 2:1 ratio of senior students (i.e., third year or higher), to junior students (i.e., first or second year), and the disciplinary distribution is similar to that of the broader university (Figure 1). The course is team-taught, with two or three instructors, and one or two teaching assistants (TAs) for approximately 45 students. The numbers have been traditionally limited by the size of the room, and the number of TAs assigned to the course; no enrolment cap was imposed by the instructors. New in 2020 was the addition of 15 graduate students and one instructor specifically for the graduate group, a change which is discussed in detail later.

One of the major aims of the ICON course is to explicitly teach important transferable skills which are needed in all careers and workplaces. These skills have been highlighted by numerous national and international reports and studies, as being both a) increasingly in demand by employers in the rapidly changing national and global labour market (Hart Research Associates, 2013; RBC, 2018; World Economic Forum [WEF], 2016), and b) not consistently, effectively, or explicitly taught by universities (Civic Action, 2018; Hill et al., 2020; RBC, 2018; Weingarten, Brumwell, Chatoor, \& Hudak, 2018). 
The transferable skills directly taught within ICON include active listening, knowledge translation and transfer, audience analysis, negotiation and compromise, ideation, group work and collaboration, and project management - all of which are assessed through a series of assignments that arise from the semester's community challenge. Assessments include but are not limited to, an audience analysis, a problem analysis, workflow contracts, knowledge translation exercises, an oral presentation for the community partner and other invited guests, and a written report that is summarized and shared with the community partners (Jacobs et al., 2017; Jacobs \& Gillis, 2016). Each of these assessments have an associated reflection requirement.

\subsection{The Structure and Approach Used in ICON}

In the first weeks, students choose their teammates and which community partner to work with through a series of facilitated team building exercises, improvisational activities, and reflections. These activities build community among class members, which creates a more supportive learning environment which can benefit student mental health. Teamwork contracts (Assignment 1) are created and signed with accountability maintained through the requirement to submit meeting minutes throughout the semester. This ensures that students remain engaged through the semester and that they are accountable to other group members. Of all the student groups that we have facilitated since the first offering of ICON (6-10 groups per semester), the instructors have only had to intervene once (Fall 2018) when a group was unable to overcome their conflict. Throughout the semester, the instructors sometimes encounter circumstances in which it is best to merge groups, split groups, or for two groups to work more closely together than with the rest. All these relationships are negotiated by students and facilitated by graduate student project managers and/or instructors, with work contracts revised. By adopting a very flexible approach to supporting student learning, the instructors and students can focus on the transferable skills curriculum.

The key to continued engagement of students throughout the semester is the emphasis on the process rather than the outcomes. In-class feedback from students over multiple cohorts indicates that they often begin the semester nervous about whether they will be able to deliver a great idea for an implementable project. The instructors are quick to correct this focus. By teaching and evaluating transferable skill development rather than final project outcomes, the course encourages students to take risks in the process (such as merging or dividing groups), because they know that it is their reflection on the process and the execution of the next step that will be evaluated. The instructors have also learned that by focusing on the process, the community partners feel welcomed in the classroom as they co-create with the student groups. The project outcomes have never disappointed and, in fact, many of them have been implemented or have effected positive change beyond the end of the course.

Throughout the semester, instructors and TAs facilitate discussions between each student team and their community partner to build the student-partner relationship. Mentorship relationships are intentionally designed in the formation of student groups that must include at least one junior student, at least one senior student, and all students must be from different academic disciplines. Instructors regularly check in with each team. This is often the first time students have worked with community partners and/or with peers with different disciplinary training, so special attention is paid to student wellbeing, and to feelings of inadequacy such as imposter syndrome. Rather than work to prevent these, students are taught resilience strategies to manage these difficult moments and work together to get out of the "pits of despair' that are commonly encountered during the research and innovation process.

\subsection{The Community Partnership Component}

ICON partners have included not-for-profit/charitable organizations, government agencies, on-campus services, and industry partners. Challenges presented to the students have included, for example, reduction of food insecurity on campus, reducing single-use plastics on campus and in the city, and developing a plan to repurpose fruit waste for use by local microbreweries (See Table 1 for community challenge details). The relationships between the instructors and the community partners are generally several months or even a year old at the time that the course begins, with instructors and partners designing the specifics of the course together, developing the outcomes, and a plan for sustainable continuity after the course.

During the Fall semester of 2020, and in partnership with local not-for-profit umbrella foundation, The Oak Tree Project, which provides funding to other local charities, students worked with community leaders from four local and national non-profit organizations to answer the question "How do we recover from the COVID-19 pandemic?", which was summarized as \#RecoverTogether. 
Table 1. Summary of Community Partner Types and Community Challenges for All ICON Offerings from Winter 2015 to Fall 2020

\begin{tabular}{|c|c|c|}
\hline Cohort & $\begin{array}{l}\text { Community } \\
\text { Partner Type }\end{array}$ & Community Challenge \\
\hline 1 & $\begin{array}{l}\text { National } \\
\text { Business }\end{array}$ & $\begin{array}{l}\text { How can we encourage Net Zero Carbon behaviours by occupants of Net Zero } \\
\text { homes? ICON students proposed five programs, ranging from community } \\
\text { building to competitive marketing strategies, to encourage occupants to } \\
\text { maximize the efficiency of their homes. }\end{array}$ \\
\hline 2 & Non-Profit & $\begin{array}{l}\text { How can we deliver sustainability education for K-12 schools accessibly and } \\
\text { inclusively? ICON students designed a mobile sustainability lab, from } \\
\text { engineering design to curriculum. }\end{array}$ \\
\hline 3 & Non-Profit & $\begin{array}{l}\text { What are the big food insecurity challenges of Ontario and how can we address } \\
\text { them? ICON students addressed a variety of problems, proposing many creative } \\
\text { ways to effect change. }\end{array}$ \\
\hline 4 & Non-Profit & $\begin{array}{l}\text { How can we reduce the size of 'urban food deserts' within our city? Students } \\
\text { proposed many projects that partnered with local food security groups. }\end{array}$ \\
\hline 5 & Non-Profit & $\begin{array}{l}\text { How can we encourage proper waste sorting, food waste reduction, and proper } \\
\text { waste reuse on a university campus? Students developed several programs for } \\
\text { the university to implement to reduce waste or ensure that it is properly treated. }\end{array}$ \\
\hline 6 & Local Business & $\begin{array}{l}\text { How can we recover farm field food waste for use in other food industries? } \\
\text { Students developed a proposal from farm to brewery for the use of farm field } \\
\text { fruits. }\end{array}$ \\
\hline 7 & $\begin{array}{l}\text { Campus } \\
\text { Services }\end{array}$ & $\begin{array}{l}\text { How can we work with commercial retail representatives to reduce waste while } \\
\text { maintaining their business model? Students proposed several projects that were } \\
\text { implemented on our campus. }\end{array}$ \\
\hline 8 & $\begin{array}{l}\text { Campus } \\
\text { Services }\end{array}$ & $\begin{array}{l}\text { How can the University of Guelph reduce its reliance on single use plastics? } \\
\text { From procurement policy to recycling management, students worked with } \\
\text { campus offices to propose many ways of reducing single-use plastic waste while } \\
\text { maintaining accessibility. }\end{array}$ \\
\hline 9 & $\begin{array}{l}\text { Local } \\
\text { Government }\end{array}$ & $\begin{array}{l}\text { How can the City of Guelph accessibly reduce the use of single-use plastics? } \\
\text { From procurement policy to recycling management, students worked with City } \\
\text { offices to propose many ways of reducing single-use plastic waste while } \\
\text { maintaining accessibility. }\end{array}$ \\
\hline 10 & $\begin{array}{l}\text { Local } \\
\text { Government }\end{array}$ & $\begin{array}{l}\text { How can the City of Guelph implement five of the recommendations made by } \\
\text { ICON cohort } 9 \text { to accessibly reduce single use plastics? Students developed } \\
\text { these five proposals further and developed implementation plans. }\end{array}$ \\
\hline 11 & $\begin{array}{l}\text { The Oak Tree } \\
\text { Project \& } 4 \\
\text { Non-Profits }\end{array}$ & $\begin{array}{l}\text { \#RecoverTogether. How can we support charity organisations in recovering } \\
\text { from the impact of COVID-19? Students partnered with four (local or national) } \\
\text { charities to pitch a Recover Together project for further funding. }\end{array}$ \\
\hline
\end{tabular}

\section{The Case Study}

\subsection{Response to COVID-19 by the University of Guelph and ICON}

Within days of the declaration of the COVID-19 pandemic on March 11th, 2020 by the World Health Organization there was a call for lockdowns to prevent the spread of the SARS-CoV-2 virus in Ontario, Canada. It became necessary to move all course delivery for the remainder of the January-April 2020 semester at University of Guelph to an online setting.

As the first wave of the pandemic hit, university administrators across Canada made the decision to move to remote delivery for the foreseeable future, including the Fall 2020 semester (Johnson et al., 2020). At the University of Guelph, administrators met in March 2020 to discuss the future delivery of all courses, including ICON. In particular, the administration recommended postponing the Fall 2020 session of ICON to Winter 2021 due to concerns regarding the 
difficulty of offering unique and interactive courses online. This decision to postpone was not limited to ICON, and included field courses, lab courses, and many other courses considered highly interactive, experiential, or hands-on. In short, the administration could not envision how these courses could effectively pivot to an online setting.

Yet, the Fall 2020 offering of ICON went ahead as scheduled for several reasons. First and foremost, this offering was based on an established reciprocal and collaborative relationship with the Oak Tree Project that began in November 2019, a type of relationship which is characteristic of most community-engaged courses (Chamberlain \& Mendoza, 2017; Levac, 2020). The instructors and the university had a responsibility to honour the community partner and the time they had already contributed to the development and delivery of ICON. Second, the instructors felt that an environment where students could be supported and engaged in relevant learning and concrete action to help address the current crisis would be especially meaningful and valuable during these challenging times.

With strong relationships, a breadth of expertise and experience, a focus on the process, and a common goal all in place, transferring ICON to a virtual and remote format required few additional resources. A comparable number of undergraduate students were enrolled as in previous semesters, plus an additional cohort of graduate students, a new component which was already intended to be implemented that semester.

The most significant change implemented in response to the COVID-19 pandemic was the topic of the collaborative challenge. The instructors understood that charitable organisations were deeply affected by the COVID-19 pandemic in many ways (Lasby, 2020), including a) reduced ability to deliver the charitable service, b) reduction in revenue, and c) reduction of in-kind support, such as volunteering. So, the instructors worked with the Oak Tree Project, prior to the start of the semester, to refocus the course on a single theme: \#RecoverTogether. This gave additional meaning and relevance to the ICON experience for students, as they were helping to develop projects to support four charities in responding to the impacts of the ongoing pandemic. No other modifications to the original plan were made. All active learning modules, assessments, engagements with community partners, and presentations were offered in a similar way to the pre-pandemic in-person ICON course. The only difference was that all students, community partners, and instructors were in the safety of their own homes.

\subsection{In the ICON Classroom Fall 2020}

All classes were hosted on Zoom ${ }^{\mathrm{TM}}$, with frequent use of breakout rooms, annotation tools, and collaborative Google Sheets ${ }^{\mathrm{TM}}$ for many of the active learning sessions. The first six weeks of the course were focused on the teaching and learning of transferable skills. ICON students and instructors gathered for a single three-hour session per week, engaging in active learning modules on the essential skills required to successfully complete the community-engaged project challenge. An expert in charitable giving also joined the class for an interactive presentation and discussion on the pandemic's impact on charities. This model of teaching transferable skills through active learning strategies, engaging with community partners, and having guest presentations from experts, is the core of the ICON model.

All active sessions, including improvisational exercises, were transferred to a remote/virtual format. Though no modifications were neeeded to any of the original learning outcomes, it was necessary to plan for a slight increase in the time needed to accomplish the lesson plans. For example, an active listening module that takes approximately 10 minutes when done in-person, took approximately 13 minutes in a remote/virtual format due to differences in individual internet speed and the occasional technological hiccup.

One of the benefits that the instructors and students experienced from working with members of the professional community as partners is the flexible way in which meetings and communication in general can be supported by technology. University instructors are often restricted to using institutionally approved software/licenses, while community organizations and businesses are not. Similarly, the motivations associated with choosing among the various technological supports are different, where institutions make choices based upon the medium sized traditional lecture course format, while businesses and community organizations emphasise collaborative functionality. ICON's interactive and collaborative format was particularly well served by having access to these alternative technological solutions.

Since the ICON course teaches transferable skills in a discipline-agnostic learning environment, the assignments can be on the topic that concerns the community partner challenge, and this allows for direct application of these new skills (Billing, 2007). In the Fall 2020 semester, the assignments were re-aligned with the \#RecoverTogether topic. For example, the Audience Analysis Assignment (Assignment 2) had students conduct an audience analysis of the members of the community organisation and then reflect upon the methods that they used, the data that they accessed, and the assumptions that they had going into conducting that analysis. This serves a double function: students learn how to analyse an audience and they learn more about the community partner that they will be working with and 
learning from throughout the semester. All assignments are scaffolded in this way to weave together the learning of skills with the motivation of relevance - creating interest and buy-in by connecting them to the real-world challenge (Christian et al., 2020).

\subsubsection{The Role of Mentorship}

The most valuable tool of engagement and retention designed for the first-year students, which has always been a part of ICON but was particularly important in the remote setting, is to be welcomed into a course with students from all year levels. First year students learn with more experienced students not only about the topics and problems addressed directly in the course, but also about how to succeed in post-secondary education. This mixed level approach is founded upon the established and growing research demonstrating the value of peer mentorship programs for first year students with senior undergraduate student mentors (eg. Boyle, Kwon, Ross, \& Simpson, 2010; Collings, Swanson, \& Watkins, 2014; Salinitri, 2005). Senior students also benefit by practicing their teaching, leadership, and mentorship skills in this model.

Even before the pandemic hit, the instructors were planning to build on this established success of mentorship experiences among the students, by incorporating graduate students into the Fall 2020 semester. To do this, a graduate level, practicum-based course called Applied Project Management was created, which had no prerequisites and was open to students from all disciplines. Project Management was chosen as the topic because it is a commonly required skill listed in job postings for professional level positions, and it is not widely taught outside of Business programs. Though only 15 graduate students (recruited via word of mouth) were enrolled in this first offering, the waitlist had an additional 30 students. The course was taught by one of the ICON instructors, with meetings held one hour before the ICON class session and student project managers joining the ICON session frequently so that they could act as Project Managers for their practicum.

Therefore, undergraduate student groups were each being managed by a graduate student who was completing a course requirement in Applied Project Management, (this was a separate role from Teaching Assistants, and the Project Managers did not do any marking of student work). Graduate students in their role as Project Managers also focused heavily on stakeholder engagement - ensuring a consistent flow of communication between student teams and the community partners (Figure 2). They were the forward face of the projects to the community partners, and they provided clarification between groups, task management, and renegotiating project terms to meet the ultimate outcome of the project. This had Project Managers work alongside faculty as mentors and managers in the project as they "led from the middle" - a unique leadership theory (Buller, 2018). The additional level of student support inherent in this model means that it would be very possible to scale up enrollment numbers in both the undergraduate and graduate courses in the future.

\section{Evidence of Effectiveness - Engagement and Curriculum}

\subsection{Methods}

An online Qualtrics survey was emailed to all students who had been registered in the Fall 2020 ICON course and the associated graduate Applied Project Management course (58 students total) on April 12th, 2021 (University of Guelph Research Ethics Board approval 20-03-031) inviting their voluntarily participation in the project. The survey consisted of 11 questions. Responses were measured using a five-point Likert scale, or by ranking options from 1 to 5 ( $1=$ most developed to $5=$ least developed). Respondents were also provided the opportunity to share further thoughts about the course.

27 students ( 47\%) opened the survey. Six of the surveys were incomplete and were eliminated from further analysis. In total, eight junior undergraduate students, nine senior undergraduate students, and four graduate students completed the survey, for a total of 21 complete responses.

\subsection{Results and Discussion}

The majority of respondents (81\%) rated their experience in the ICON classroom as positive or extremely positive. Most students also reported that this was their first experience working with a community partner (80\%), or working with students from another discipline (67\%). Respondents were more likely than not to indicate that they felt supported by both the instructors and other students throughout the process, and that the course offered skills training that would be practical to them outside of the classroom. All but one student agreed or strongly agreed that the course was unique, and $86 \%$ indicated they would like to see more courses like ICON offered in higher education programs. More than three quarters of respondents indicated they would enroll in the course again if they had the opportunity. One student commented, 
...even when I was a bit confused I never felt too stressed, because I knew I had the support of the professors and my group members. This course was an awesome experience. I wish it had lasted two semesters instead of one! (Senior undergraduate student, ICON Fall 2020)

The diversity of year levels and programs working together was super neat and definitely added to the experience. (Junior undergraduate student, ICON Fall 2020)

I really enjoyed taking this course and found the content and experiences really valuable. (Graduate student, ICON Fall 2020).

Had a lot of real-world application and was very much a real-world problem that we were working on which made the work seem more purposeful and personal. (Junior undergraduate student, ICON Fall 2020)

When asked to compare their ICON experience to other courses they took during the same remote learning semester (Fall 2020), 89\% indicated that it was more or a lot more engaging, 95\% indicated it was more or a lot more interactive, $62 \%$ said it was more or a lot more accessible, and $84 \%$ said it was more or a lot more welcoming and inclusive. Further, a majority of students agreed that the course made them feel more or a lot more connected to campus (68\%) and to the community (84\%) compared to their other classes.

In terms of skills development, students reported that they agreed or strongly agreed that the course allowed them to expand their networks (71\%), and improve communication (81\%), group work (90\%), and problem-solving skills $(90 \%)$.

The skills I learned in this course can and will be applied to the ways that I analyze problems ... in all of my other ... courses. (Senior undergraduate student, ICON Fall 2020)

I found the course highly enjoyable and really grounded my leadership skills. (Senior undergraduate student, ICON Fall 2020)

Further, when asked to rank group work, critical thinking, communication, leadership, and project management skills based on which they felt were most developed by attending the ICON classroom (on a scale of 1 to 5, with 1 being the top-rated skill), students ranked group work and leadership skills highest (average rank of 2.4 and 2.9 respectively). Project management, critical thinking, and communication skills followed these. Interestingly, junior students ranked group work and project management equally as those they feel they developed the most. Senior students ranked group work first, closely followed by leadership skills, while graduate students ranked critical thinking first, followed by leadership skills. It's important to note, however, that students felt they developed each of these skills in the ICON classroom.

This was a great experience and I'm so grateful for the opportunity. While I had to rank skills, I feel I gained all of the above listed skills - but my communication and teamwork skills improved the most. (Graduate student, ICON Fall 2020).

Finally, students were given the opportunity to provide further comments about the ICON classroom. Most students provided positive feedback of their experience, indicating that they felt supported by the instructors and teaching assistants and their group members, and that ICON was the "Most hands-on, relevant course" they had taken at the University of Guelph. Students also stated that the skills learned in the classroom could and would be applied to approaches to analysis in other courses within their degrees. One student suggested that the course "should be a mandatory course" and another commented about how ICON helped them integrate socially, which is shown to improve student retention (Tinto, 1993).

Most of my courses said to me, 'Here's the problem. This is why it's a problem. This is who it's affecting'. This course said to me, 'Here's how to look at the problem to fully understand it. Here's how to go about finding solutions. Here's how to effectively work with others to workshop solutions. Here's how to solve a problem.' (Senior undergraduate student, ICON Fall 2020)

This was the most rewarding and impactful class of my entire educational experience. (Graduate student, ICON Fall 2020).

Not only was the course extremely relevant to the real world, but it also made my first-year experience so much better. I have no friends from my high school who go to U of G, but through ICON, I met my best friend!!! (Junior undergraduate student, ICON Fall 2020)

Students also identified areas where the delivery of the ICON classroom could improve. This included increased contact time with experts from the Community Engaged Scholarship Institute (CESI) at the University of Guelph and 
more discussion early in the semester to help students set expectations. In the former case, increased contact with CESI could help students, particularly junior students, better understand their role in community-engaged work and the needs of their community partner. In the latter case, further discussion and activities on setting expectations-within teams, within the classroom, and with the community partner, could help students better manage stress and reduce conflict.

One student indicated they were completely disappointed with the experience and felt that the work they were doing was not community oriented. This student also indicated that they did not feel supported by the instructors or by their classmates. While the majority of survey respondents had a positive experience with ICON, we appreciate and value the experiences of all ICON students and see this student's dissatisfaction as an opportunity to reflect on and adjust our model as we move forward in the virtual space and eventually to the in-person space as well.

\section{Concluding Remarks}

The COVID-19 pandemic spread our students out around the world, challenging our ability to ensure that they remained connected, both technologically and socially. As a key pedagogical tool of ICON, connectivity is a priority; by focusing on the building of relationships among our community partners, students, and the instructors, we learned to use the technology as a means of enhancing interactions and learning. By changing the challenge topic to \#RecoverTogether, we added relevance without increasing trauma, as many students had experienced personal loss and were finding other course references to the current tragedy of the pandemic to be traumatizing. Even though most students were not physically in Guelph, they connected regularly with the community partners who were here, and met other students from their year level and higher, shared experiences from their homes, and learned together during these challenging times.

Huish (2020) describes three essential processes for the humanisation of pedagogy in the context of experiential learning that the COVID-19 pandemic has offered in what they describe as a 'crisis of opportunity': 1) making of meaning, 2) use of digital teaching and learning tools to create inclusive curriculum that reduces the hierarchical imbalance imposed by traditional in-person teaching environments, 3) acknowledging that COVID-19 is a shared global experience that, in itself, is a reminder for the importance of practicing the skill of active listening. These were essential components of the success of ICON during a pandemic, where students identified 'group work' as being the top ranked learned skill despite our remote teaching and learning format. By changing the topic, which was easily done due to the discipline-agnostic curriculum, to \#RecoverTogether, and by moving outside of the traditional classroom so that all students could engage using a variety of tools, we maintained our ability to build a sense of community among the students, instructors and community partners.

Despite initial concerns from the administration about the feasibility of running an interactive, experiential, community-engaged learning experience such as ICON during the remote Fall 2020 semester, it was clearly very successful. The course had no reduction in enrollments, with numbers actually increasing due to the new graduate course component, no student attrition during the semester, and the results of the student survey demonstrate that students found the class to be more engaging, interactive, and inclusive than other courses in the same remote semester. Students also found the ICON class made them feel more connected to both the campus community, and the local community in our city, than their other courses that semester. During a time of increased isolation for students, this sense of connection is particularly valuable.

In reflecting upon the ICON experience, we realized that the virtual remote format could have supported many more students. The in-person course capacity is restricted primarily by the size of the classroom that we use, and the number of teaching assistants assigned to the course. In a virtual and remote format, we could have doubled course enrollment with the addition of one teaching assistant, which would remove another barrier to participation and expand the reach of the course to even more students.

The importance of providing first year students with course-based access to peer mentorship by senior undergraduate and graduate students cannot be understated. Though we have become accustomed to witnessing the academic and personal benefits in the ICON classroom, we found that we were re-recognizing them in the context of teaching during a pandemic. Peer mentorship, especially when offered to first year students (Lane, 2020) emerges as a powerful tool by which to improve social integration and student retention (Tinto, 1993). Yet access to mentorship usually remains outside of core curricular learning, which presents significant barriers to students who may not be able to take on non-curricular learning opportunities. When offered within the curriculum, in a course for credit such as ICON, the benefits of having a mentor become more accessible and inclusive. 
Though it has been suggested that the direct transfer of courses to remote learning formats is not supportive of the "personal, psychological, and logistical concerns of students and professors" (Christian et al., 2020, p 2), we found the exact opposite because the ICON course content is discipline-agnostic and could therefore adopt the constructivist (Biggs, 1996) approach to individual meaning-making by changing only the topic. In our experience with ICON, by focusing on the teaching and learning of transferable skills and thus the removal of the importance of topic content, we were able to easily change the topic to increase the relevance of student learning. Our approach to teaching ICON, which is also format agnostic, transferred smoothly to the online/remote format. So, while it is true that most courses that are offered in traditional lecture style with an emphasis on content knowledge learning did not transfer well to online formats, we suggest that courses built upon transferable skills learning using evidence-informed teaching practices can be engaging and community-building in any format during challenging times.

\section{Distribution of Students in the ICON Classroom (September - December, 2020) by Discipline and Student Type}
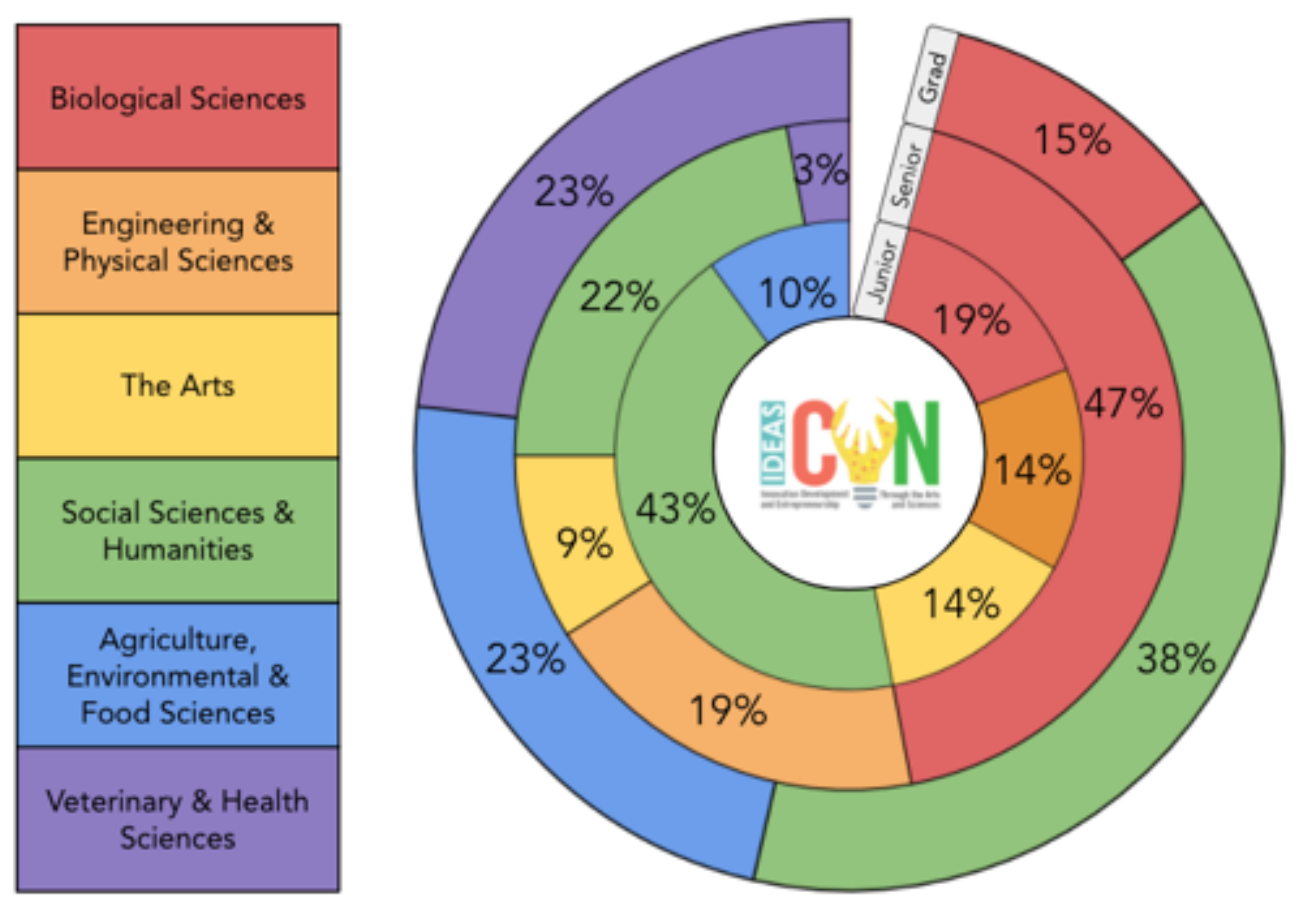

\section{Distribution of Students in the ICON Classroom (September - December, 2020) by Community Partner and Student Type}

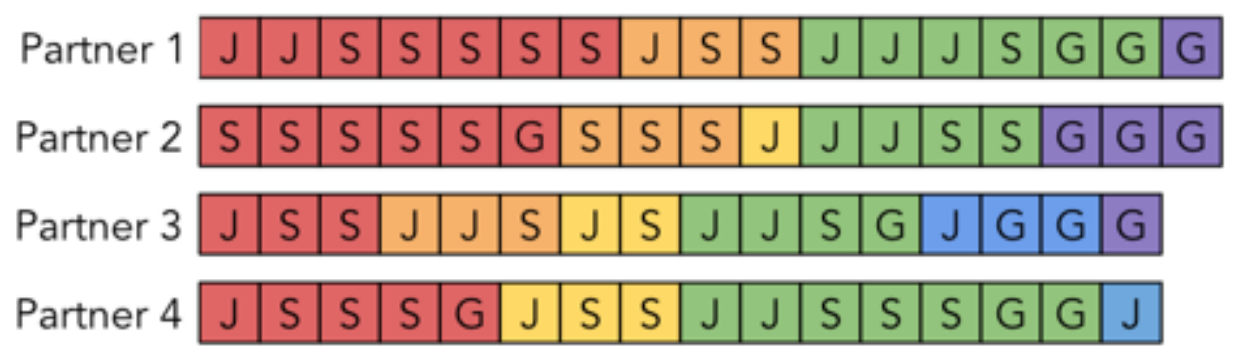

Figure 1. Disciplinary profile of the September-December (Fall) 2020 of ICON semester showing the distribution of junior ( $\mathrm{J}$, inner ring) and senior undergraduate (S, middle ring) students and graduate students (G, outer ring) from different discipline areas across the university, within the course and within each Community Partner project group 


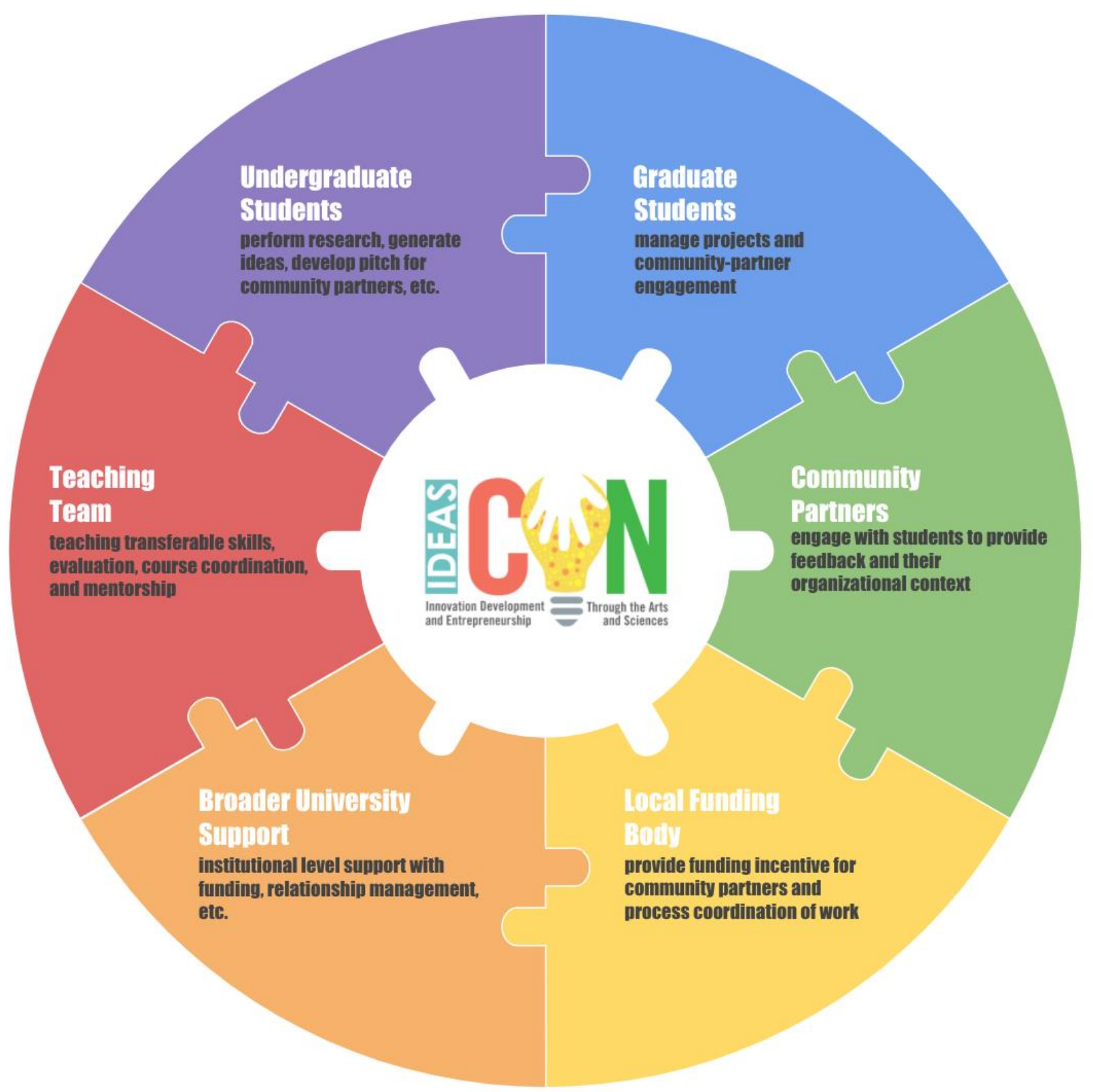

Figure 2. The roles of each of the participants and stakeholders within the ICON course structure

\section{Acknowledgements}

The Dish with One Spoon Covenant speaks to our collective responsibility to steward and sustain the land and environment in which we live and work, so that all peoples, present and future, may benefit from the sustenance it provides. As we continue to strive to strengthen our relationships with and continue to learn from our Indigenous neighbours, we recognize the partnerships and knowledge that have guided the learning and research conducted as part of this work. We acknowledge that the University of Guelph resides in the ancestral and treaty lands of several Indigenous peoples, including the Attawandaron people and the Mississaugas of the Credit, and we recognize and honour our Anishinaabe, Haudenosaunee, and Métis neighbours. We acknowledge that the work presented here occured on their traditional lands so that we might work to build lasting partnerships that respect, honour, and value the culture, traditions, and wisdom of those who have lived here since time immemorial.

We are grateful to all our community partners including the Guelph Community Foundation, The Letter M Marketing, and Pearl Street Communications for their collaboration. IdeasCongress is built upon the work and feedback of our students, supportive administrators, and fellow colleagues who have journeyed with us since 2014. Funding was provided by the Food from Thought program at the University of Guelph (funded in part by a grant from the Canada 
First Research Excellence Fund) in the form of MSc funding to Author 2. IdeasCongress seed funding was provided by the Provost of the University of Guelph in 2014 and 2015.

\section{References}

Biggs, J. (1996). Enhancing teaching through constructive alignment. Higher Education, 32(3), 347-364. https://doi.org/10.1007/BF00138871

Billing, D. (2007). Teaching for transfer of core/key skills in higher education: Cognitive skills. Higher Education, 53(4), 483-516. https://doi.org/10.1007/s10734-005-5628-5

Boyle, F., Kwon, J., Ross, C., \& Simpson, O. (2010). Student-student mentoring for retention and engagement in distance education. Open Learning: The Journal of Open, Distance and e-Learning, 25(2), 115-130. https://doi.org/10.1080/02680511003787370

Buller, R. (2018). Leading from the middle: An overview of current research and trends on the topic. Journal of Access Services, 15(1), 44-56. https://doi.org/10.1080/15367967.2018.1423982

Burgstahler, S. E., \& Cory, R. C. (2008). Universal Design in Higher Education: From Principles to Practice. In Harvard Education Press. Harvard Education Press.

Chamberlain, L., \& Mendoza, S. (2017). Design Thinking as Research Pedagogy for Undergraduates: Project-Based Learning with Impact. Council on Undergraduate Research Quarterly, 37(4), 18-22. https://doi.org/10.18833/curq/37/4/15

Christian, D. D., McCarty, D. L., \& Brown, C. L. (2020). Experiential Education during the COVID-19 Pandemic: A Reflective Process. Journal of Constructivist Psychology, 1-14. https://doi.org/10.1080/10720537.2020.1813666

Civic Action. (2018). Now Hiring: The Skills that Companies Want that Young Canadians Need. https://civicaction.ca/app/uploads/2021/03/SkillsConnect_NowHiring_Dec_2018_DIGITAL.pdf

Collings, R., Swanson, V., \& Watkins, R. (2014). The impact of peer mentoring on levels of student wellbeing, integration and retention: A controlled comparative evaluation of residential students in UK higher education. Higher Education, 68(6), 927-942. https://doi.org/10.1007/s10734-014-9752-y

Gallagher, S., \& Palmer, J. (2020, September 29). The Pandemic Pushed Universities Online. The Change Was Long Overdue. Harvard Business Review. https://hbr.org/2020/09/the-pandemic-pushed-universities-online-the-change-was-long-overdue

Gillis, D., Nelson, J., Driscoll, B., Hodgins, K., Fraser, E., \& Jacobs, S. (2017). Interdisciplinary and Transdisciplinary Research and Education in Canada: A Review and Suggested Framework. Collected Essays on Learning and Teaching, 10, 203-222. https://doi.org/10.22329/celt.v10i0.4745

Hart Research Associates. (2013). It Takes More Than a Major: Employer Priorities for College Learning and Student Success, https://www.aacu.org/publications-research/periodicals/it-takes-more-major-employer-priorities-college-learnin g-and

Hill, M. A., Overton, T., Kitson, R. R., Thompson, C. D., Brookes, R. H., Coppo, P., \& Bayley, L. (2020). 'They help us realise what we're actually gaining': The impact on undergraduates and teaching staff of displaying transferable skills badges. Active Learning in Higher Education, 146978741989802. https://doi.org/10.1177/1469787419898023

Hodges, C., Moore, S., Lockee, B., Trust, T., \& Bond, A. (2020, March 27). The Difference Between Emergency Remote Teaching and Online Learning. https://er.educause.edu/articles/2020/3/the-difference-between-emergency-remote-teaching-and-online-learning

Huish, R. (2021). Global citizenship amid COVID-19: Why climate change and a pandemic spell the end of international experiential learning. Canadian Journal of Development Studies / Revue Canadienne d'études Du Développement, 1-18. https://doi.org/10.1080/02255189.2020.1862071

Jacobs, S., \& Gillis, D. (2016). Innovation Through Transdisciplinary Training, 10. https://doi.org/10.22329/celt.v10i0.4745

Jacobs, S., Nelson, J., Driscoll, B., \& Gillis, D. (2017). Hijacking All The Courses: A Transdisciplinary Learning Experience for Undergraduate Students. Discussions on University Science Teaching: Proceedings of the Western Conference on Science Education, 1, 5. https://ojs.lib.uwo.ca/index.php/wcsedust/article/view/3789 
Johnson, N., Veletsianos, G., \& Seaman, J. (2020). Canadian Higher Education in Fall 2020: Multiple Online and Hybrid Learning Scenarios (Canadian Pulse Project, p. 4). Canadian Digital Learning Research Association. https://onlinelearningsurveycanada.ca/wp-content/uploads/2020/05/2020_pulse_fallplans_en-1.pdf

Lane, S. R. (2020). Addressing the Stressful First Year in College: Could Peer Mentoring Be a Critical Strategy? Journal of College Student Retention: Research, Theory \& Practice, 22(3), 481-496. https://doi.org/10.1177/1521025118773319

Lasby, D. (2020). Charities \& the COVID-19 Pandemic (Sector Monitor, p. 22). Imagine Canada. https://imaginecanada.ca/sites/default/files/COVID-19\%20Sector\%20Monitor\%20Report\%20ENGLISH_0.pdf

Levac, L. (2020). Negotiating tensions in a community engaged and intersectionality-informed political science course. Politics, Groups, and Identities, 8(1), 194-202. https://doi.org/10.1080/21565503.2019.1605297

MarketScale. (2020, October 14). College Faculty and Administrators Feel Prepared to Teach Online This Fall. MarketScale. https://marketscale.com/industries/education-technology/college-faculty/

Mishra, L., Gupta, T., \& Shree, A. (2020). Online teaching-learning in higher education during lockdown period of COVID-19 pandemic. International Journal of Educational Research Open, 1, 100012. https://doi.org/10.1016/j.jedro.2020.100012

Office of Institutional Research and Planning. (2020). University of Guelph-Fact Book 2019-2020 (p. 75). University of Guelph. https://www.uoguelph.ca/about/doc/UofG-Fact-Book-2019-2020.pdf

Royal Bank of Canada. (2018). Humans Wanted: How Canadian youth can thrive in the age of disruption. https://www.rbc.com/dms/enterprise/futurelaunch/_assets-custom/pdf/RBC-Future-Skills-Report-FINAL-Single s.pdf?_ga=2.11894580.1850951702.1605040349-533286703.1605040349

Salinitri, G. (2005). The Effects of Formal Mentoring on the Retention Rates for First-Year, Low Achieving Students. Canadian Journal of Education / Revue Canadienne de l'éducation, 28(4), 853. https://doi.org/10.2307/4126458

Schwartzman, R. (2020). Performing pandemic pedagogy. Communication Education, 69(4), 502-517. https://doi.org/10.1080/03634523.2020.1804602

Tinto, V. (1993). Leaving College: Rethinking the Causes and Cures of Student Attrition. Second Edition. University of Chicago Press, 5801 South Ellis Avenue, Chicago, IL 60637. https://doi.org/10.7208/chicago/9780226922461.001.0001

UNESCO Education Sector. (2020a). COVID-19 Crisis and Curriculum: Sustaining Quality Outcomes in the Context of Remote Learning (4.2; COVID-19 Education Response Issue Notes). https://unesdoc.unesco.org/ark:/48223/pf0000373273/PDF/373273eng.pdf.multi

UNESCO Education Sector. (2020b). TVET Systems and Labour Markets (5.2; COVID-19 Education Response Issue Notes). https://unesdoc.unesco.org/ark:/48223/pf0000373274.locale=en

UNESCO Education Sector. (2020c). Higher Education Institutions' Engagement with the Community (5.3; COVID-19 Education Response Issue Notes). https://unesdoc.unesco.org/ark:/48223/pf0000374128.locale=en

UNESCO Education Sector. (2020d). Education in Crisis: Are Higher Education Teachers Leading in Action? (World Teacher's Day 2020) [Synthesis Report]. https://unesdoc.unesco.org/ark:/48223/pf0000374750.locale=en

Weingarten, H. P., Brumwell, S., Chatoor, K., \& Hudak, L. (2018). Measuring Essential Skills of Postsecondary Students: Final Report of the Essential Adult Skills Initiative (p. 74). Higher Education Quality Council of Ontario. https://heqco.ca/wp-content/uploads/2020/02/FIXED_English_Formatted_EASI-Final-Report2.pdf

World Economic Forum. (2016). The Future of Jobs: Employment, Skills and Workforce Strategy for the Fourth Industrial Revolution (Global Challenge Insight Report). http://www3.weforum.org/docs/WEF_Future_of_Jobs.pdf

\section{Copyrights}

Copyright for this article is retained by the author(s), with first publication rights granted to the journal.

This is an open-access article distributed under the terms and conditions of the Creative Commons Attribution license (http://creativecommons.org/licenses/by/4.0/). 